\title{
Teologia Política Emancipadora: convergência possível entre ateísmo e mística
}

Orientador: Paulo Fernando Carneiro de Andrade

Doutorando: Valdemar Figueredo Filho

Área de Concentração: Teologia Sistemático-Pastoral

Linha de Pesquisa: Religião e Modernidade

Projeto de Pesquisa: Crise da modernidade e teologia latino-americana

Analiso nesta pesquisa bibliográfica a mística cristã como promotora da emancipação humana. A definição de Modernidade enquanto autonomia humana fica relacionada com ambiente supostamente fértil para gerar ateus. Esta inferência encontra óbices decisivos. A teologia política emancipadora pode até ter início na experiência mística em que ocorrem fenômenos como o êxtase e a contemplação, no entanto, ela só será completa se for promotora da práxis, ações sociais públicas situadas na história. Entre ateus e místicos o elo possível é a emancipação humana. O sentido de hermenêutica, conforme o concebe Paul Ricoeur, se constitui como importante marco metodológico e teórico. O ateísmo Moderno é descrito pelas biografias e bibliografias pontuais dos "mestres da suspeita" (Ludwig Feuerbach, Karl Marx, Friedrich Nietzsche e Sigmund Freud), enquanto o sentido de místico não é representado na retórica apologética, mas na expressão do testemunho, seja dos filósofos (Henri Bergson, Paul Ricoeur e Gianni Vattimo) ou de teólogos (André Torres Queiruga, Jurgen Moltmann e John Baptist Metz). As melhores definições de fé são experiências existenciais. A teologia política é teologia se é mística. O ânimo trazido pela experiência com o Espírito Santo conduz a práxis do seguimento a Jesus, em que a face de Deus é buscada e a face do próximo é encontrada.

Palavras-chave: Comunicação Política. Ateísmo. 